кандидат педагогічних наук, старший викладач

(НУ "Львівська Політехніка")

oksanabaglay@yahoo.com

ORCID : $0000-00 \odot 3-1040-8483$

\title{
КУЛЬТУРОЛОГІЧНИЙ ПІДХІД ДО ПРОФЕСІЙНОЇ ПІДГОТОВКИ МАЙБУТНЬОГО ФАХІВЦЯ ТУРИСТИЧНОГО ПРОФІЛЮ
}

У статті обтрунтовується значущіссть культурологічного підходу до професійної підготовки майбутнього фахівия туристичного профілю до здійснення міжскультурної комунікативної взаємодії.

Зазначено, щуо задоволення постійно зростаючих потреб споживачів туристичного ринку послуг $\epsilon$ актуальною проблемою. Наголошено, щчо професійна підготовка фахівия цієєї галузі повинна бути націлена на забезпечення високого рівня теоретичної та практичної підготовки фахівия, готового до здійснення професійної та комунікативної взаємодії зі споживачами туристичних послуг.

Міжкультурна комунікативна взаємодія розглядається як иілеспрямований зв'язок між представниками різних культур, завдяки якому відбувається обмін інформацією, культурними та духовними цінностями

з урахуванням унікальності кожної з культур, у професійній діяльності для задоволення потреб туристів. Наведено основні аспекти професійної підготовки майбутнього фахівия туристичного профілю для здійснення міжкультурної комунікативної взаємодії у професійній діяльності.

Ключові слова: професійна підготовка, майбутній фахівецьь туристичного профілю, туристична комунікація, міжкультурний діалог, міжкультурна комунікативна взаємодія, задоволення потреб туриста.

Постановка проблеми в загальному вигляді та її зв'язок 3 важливими науковими та практичними завданнями. Сучасний розвиток цивілізації розглядається крізь призму їі складових економіки, соціальної сфери і духовної культури. Глобальним чинником, який торкається кожної 3 наведених вище складових, є світовий туризм як соціальний феномен, надзвичайно багатим за змістом і проявами. Туризм безпосередньо впливає на стабільність у суспільстві, виховуючи толерантність і гостинність, формує комунікативну культуру й народну дипломатію, тим самим консолідуючи націю.

На початку XXI ст. стала глобально розвиватися сфера туризму, що спричинено добровільною тимчасовою міграцією великих потоків людей в інше середовище з певною туристичною метою. Завдяки таким масовим подорожам людей в інше соціокультурне середовище інтенсифікуються міжкультурні комунікації, що передбачає проінформованість учасників цих процесів у різних галузях знань, активнішими стають економічні й культурні зв'язки між етносами і народами. Особливо актуальною стає проблема задоволення потреб споживачів туристичного ринку послуг.

Туристичні послуги розкривають внутрішній світ людини у нових аспектах, що супроводжується виникненням нових емоцій і психологічним розвантаженням. У цьому процесі нелінійним шляхом розвиваються інтелектуальні, чуттєві, пізнавальні зусилля, спрямовані на збагачення соціального досвіду, незалежно від фінансового статусу людини (в чому деякою мірою й виявляється демократизм туризму). Тому особлива увага має приділятися підготовці кадрового забезпечення цієї галузі.

Аналіз останніх досліджень і публікацій, у яких започатковано розв'язання проблеми. Дослідження проблеми професійної підготовки фахівців для галузі туризму здійснювали І. Зорін, Л. Кнодель, В. Лозовецька, С. Фокін, Н. Хмілярчук $\quad$ В. Христюк, Г. Цехмістрова; застосування міжкультурного підходу до їхньої підготовки - В. Пазенок, Е. Слободенюк, В. Федорченко та ін.

Незважаючи на вагомі результати роботи дослідників, проблема ефективної підготовки майбутнього фахівця туристичної галузі як спеціаліста, здатного вести міжкультурну комунікативну взаємодію на високому професійному рівні для задоволення постійно зростаючих потреб споживачів галузі, залишається актуальною.

Формування мети статті. Метою статті є обгрунтування значущості культурологічного підходу до професійної підготовки майбутнього фахівця туристичного профілю для здійснення міжкультурної комунікативної взаємодії.

Виклад основного матеріалу дослідження 3 повним обгрунтуванням отриманих наукових результатів. У словниках і довідниках з сучасного туризмознавства зафіксовано зміст основних понять, які вживаються на різних рівнях у туристичній діяльності, зокрема, це "туризм", "міжнародний туризм", "дипломатія" і "народна дипломатія". Під "народною дипломатією" розуміють обмін делегаціями від недержавних установ, громадських організацій та об’єднань, які під час міжкультурної комунікації репрезентують суспільні інтереси, але з неофіційних позицій. Завдяки "народній дипломатії" формуються світогляд, двосторонні та багатосторонні відносини у міжнародній та міжнаціональній співпраці, розвивається демократичний рух і міжнародне спілкування молоді, визначаються соціальні й групові 
пріоритети солідарних відносин. Оскільки з розвитком взаємовигідного співробітництва між різними соціальними групами встановлюються різнобічні демократичні зв'язки з навколишнім світом, завданням народної дипломатії є їх захист [1: 49].

Значення туризму як чинника "народної дипломатії" особливо зростає на фоні тих трагічних подій, які останніми десятиліттями відбувалися і продовжують відбуватися в різних країнах світу, зокрема в Україні. Проте, на якому б рівні не складалися міжнародні відносини, учасники цих процесів мають бути готовими до продуктивного міжкультурної взаємодії.

Сучасні вимоги, які ставляться перед фахівцями туристичної галузі з боку роботодавців та споживачів туристичних послуг зумовлені конкуренцією на ринку праці. Саме тому професійна підготовка фахівця цієї галузі повинна бути націлена на забезпечення високого рівня їх теоретичної та практичної підготовки, готовності до здійснення професійної, а також комунікативної взаємодії зі споживачами туристичних послуг.

Незважаючи на те, що туристична освіта в Україні здійснює підготовку фахівців на достатньо високому рівні, прослідковується певна проблема забезпечення галузі потенційними кадрами, зумовлена доволі низьким рівнем співпраці навчальних закладів туристичного профілю та підприємств туристичної галузі [2: 36]. Тому важливими є також такі напрями спільної діяльності, як інтеграція роботи фахівців сфери туризму та закладів освіти шляхом проведення консультацій, виконання практичних завдань, участі у тренінгах тощо. Необхідна участь викладацького складу в професійній діяльності сектора туризму (праця у фірмах екскурсоводами, туроператорами тощо). Якісним результатом цієї співпраці $\epsilon$ інтеграція готовності й здатності випускників виконувати професійну діяльність.

Н. Ничкало, проаналізувавши теоретичні матеріали з проблем педагогіки, психології і туризму як складової теорії і методики професійної освіти, зазначила, що одним 3 найважливіших аспектів професійної туристичної освіти в Україні є обгрунтування та дослідження саме культурологічних засад професійної освіти туристичного профілю [3: 258].

Завдяки мережі туристичної комунікації виникає глобальна синергія культур, коли вони розвиваються й удосконалюються при безумовному збереженні самобутності. Туристи і місцеве населення розглядаються як носії гуманітарних цінностей, якими вони обмінюються під час спілкування. У результаті процесів комунікації між ними спостерігаються активізація та поглиблення взаємодії, взаємовплив, взаємопроникнення і взаємозбагачення культур. Тому туристична діяльність через систему різних соціальних установ здатна спричинити "безпосередню (шляхом прямого контакту своїх представників) гуманізовану комунікацію соціумів, а також їх взаємодію на основі вироблених у соціальному дискурсі людино центричних параметрів порядку (в тому числі соціальних), зорієнтовує на гуманітарні цінності, соціальні програми, проекти, цілі, ідеали та сприяє самоорганізації гуманного глобального соціуму" [4: 14].

Широкий спектр спеціалізацій фахівців туристичного профілю зумовлений необхідністю забезпечення різноманітних потреб споживачів туристичного ринку [5]. У туристичних установах повинні працювати висококваліфіковані фахівці, що володіють основними іноземними мовами. Практика показує, що безпосередньо, без участі перекладачів, спілкування менеджерів як 3 керівниками груп, так і з туристами сприяє створенню хорошого робочого ритму, швидкому розв'язанню питань, що виникають, більшій довірі й кращому ставленню іноземців до функціонерів туристичних організацій. У штатах готелів і туристичних баз, ресторанів та кафе, які обслуговують іноземних туристів, повинні бути висококваліфіковані працівники (адміністратори, портьє, офіціанти, бармени, швейцари, кіоскери, касири у пунктах обміну валюти), що володіють іноземною мовою в обсязі, необхідному для виконання своїх службових обов'язків. При підготовці номерного фонду треба використати рекламні буклети мовою країни, з якої приїхала дана туристична група. У вестибюлях, холах, концертних залах потрібно обладнати спеціальні стенди 3 інформацією про розташування служб готелю, можливості отримання додаткових послуг, зокрема, на різних мовах. Особливої уваги заслуговує підбір у готелі літератури іноземними мовами: тут і краєзнавчі довідники, карти-схеми тощо [6: 120].

Іноземні туристи потребують допомоги досвідчених гідів-перекладачів. У роботі гіда-перекладача основною умовою, що визначає успіх, є творчий підхід, уміння врахувати контингент груп і власне ставлення гіда-перекладача до того, про що розповідає. Інформаційні можливості іноземного туризму, а соціального особливо, надзвичайно великі. Сьогодні від кожного гіда-перекладача вимагається не лише знання великого фактичного матеріалу, а й уміння залучати його в текст екскурсії, враховуючи контингент групи, соціальний склад іноземних туристів. При виконанні екскурсій, соціальної та культурно-видовищної програми перекладач повинен: вивчати матеріали методичних посібників щодо маршруту; перебувати 3 групою i вести усний переклад на всіх планових i додаткових заходах [6: 121-122].

Сьогодні в гуманітарній сфері набуває особливого звучання ціннісне освоєння світу, яке передбачає, передусім, взаємоповагу один до одного, культуру спілкування, вияв толерантності. ХХІ століття розглядається як переломний етап у зміні ставлення до природи, людини, конкуренції в політиці та 
економіці, орієнтація його на людино-орієнтовану модель. Зростає значення етики спілкування, що передбачає посилену увагу до формування комунікативної культури, яка є однією 3 ланок концепції "нового гуманізму" [1: 11]. У цьому аспекті провідна роль належить туристичним комунікаціям, здатним організувати щире, добровільне спілкування. Щоб результативність спілкування була продуктивною, потрібна власна зацікавленість у цьому, прикладання вольових зусиль, вміння домовлятися, налаштовуватися на доброзичливі відносини.

Оскільки сьогодні планета поділена на різні регіони туристи беруть активну участь у комунікації 3 представниками різних етнічних об'єднань, на території яких розташовані рекреаційні зони і туристичні об’єкти. Тому при аналізі структури культури соціальної групи та розвитку іiі динаміки необхідно враховувати постійне перебування на території корінних жителів значної кількості представників інших культур, в результаті чого має місце ефект туристичної крос-культурної міжрегіональної комунікації. Цей ефект визначається зростанням інтенсивності контактів, взаємодії та комунікації представників різних соціальних груп і етносів, в результаті чого активізується обмін цінностями між представниками соціумів, стає можливою координація дій у різних сферах суспільного життя [1: 66].

У цьому контексті можна зазначити, що підвищення рівня професійної підготовки працівників туристичної сфери до комунікативної взаємодії з представниками різних соціумів залежить від якості їх підготовки до міжкультурного спілкування, а також рівня володіння іноземною мовою та знання відмінностей потреб різних категорій туристів. У контексті формування досвіду продуктивної толерантної міжкультурної комунікативної взаємодії майбутніх фахівців Н. Якса наводить його складові, а саме: соціокультурне оточення, виховання і практика, які реалізуються через освіту; ознайомлення із світовою культурою з одночасним залученням до загальнолюдських цінностей та стандартів існування; формування духовного потенціалу i нового мислення у контексті громадянських прав людини; сприйняття історії свого народу крізь призму історичного минулого своєї країни й людства, а себе - як носія національних цінностей і відповідального за майбутнє всього людства; формування розуміння цілісності сучасного світу, взаємозалежності всіх подій і процесів, необхідності об'єднання зусиль представників різних культур для вирішення глобальних проблем людства; визнання рівності та достоїнств усіх культур і права представників інших культур зберігати свою культурну самобутність тощо [7: 44]. Міжкультурна складова професійного спілкування допомагає студентові сформувати цілісне уявлення про освіту, спроектовану на основі діалогу культур, що дає змогу прилучити майбутніх фахівців до світової культурної спадщини.

Професійна підготовка фахівця туристичного профілю, 3 точки зору ведення міжкультурної інтерактивної взаємодії, передбачає врахування аспекту міжкультурного діалогу при здійсненні процесі цієї підготовки. Л. Євдокімова-Лисогор трактує міжкультурний діалог фахівця туристичної галузі як "професійну й ділову взаємодію з представниками різного культурного й мовного походження, набуття творчих умінь діалогічної взаємодії в ситуаціях професійної діяльності" [8: 8]. 3 огляду на вищесказане, міжкультурну комунікативну взаємодію можна розглядати як цілеспрямований зв'язок між представниками різних культур, завдяки якому відбувається обмін інформацією, культурними та духовними цінностями з урахуванням унікальності кожної з культур у професійній діяльності для задоволення потреб туристів та результативного ведення міжкультурного діалогу.

Для уникнення комунікативних суперечностей необхідно розуміти контексти, які можуть бути: контекст реальної ситуації та контексти кожного з учасників комунікації. Розуміння контекстів $\epsilon$ методом пізнання діалогу культур, який можна розглядати як засіб комунікативної взаємодії між окремими людьми чи групами людей, які є представниками різних культур.

Тому, варто зазначити, що результатом правильно організованого діалогу між представниками різних культур є взаєморозуміння. "Діалог, що містить у собі все накопичене людством комунікативне багатство - бесіду і суперечку, конкуренцію і співробітництво, тираду й опонування - розвиває в особистості як самоповагу, так і повагу до інших". Турист, як правило, - це людина "діалогічного стилю" [9: 31], насичена культурними якостями, притаманними соціуму, до якого він належить.

Разом із прогресом в інформатизації суспільства 3'явились такі негативні явища як: брак контактів i спілкування між людьми, комунікативна обмеженість, самотність. Для зменшення негативних наслідків інформатизації суспільства необхідно активізувати діалогічні зв'язки як основу сучасної комунікативної культури для здійснення міжкультурного діалогу.

Саме тут важливу роль відіграє саме культуротворча функція туризму, яка, як зазначає О. Головашенко, формується на основі використання моделі взаємодії чотирьох культур: культура того регіону, звідки приїжджають туристи; дозвіллева культура; самобутня культура місцевих жителів; культура обслуговування. Комунікативна культура має бути адекватною сучасному рівню розвитку цивілізації для ефективного ведення комунікації [10].

Міжкультурна комунікація відбувається між носіями різних культур, у ході якої комуніканти проявляють свій досвід, знання і цінності, тим самим виявляючи суть культури. Тому більшість зарубіжних учених розглядає їі як взаємодію між представниками різних культур, яка має подвійну 
природу - це особлива галузь людських відносин, що об'єднує комунікацію і культуру. Грунтуючись на концептуальних положеннях психологів, можна визначити міжкультурну комунікацію як взаємодію культур, що здійснюється в певному просторі й часі; культурні контакти, які набувають різних форм, знаходять своє вираження у зближенні, синтезі, додатковій інформації, діалозі, отримують своє вираження через мову; у даному вигляді комунікації взаємодіють (відбуваються) через мову, культуру і особистість.

Аналізуючи дослідження у сфері міжкультурної комунікації, можна зробити висновок про те, що увага вчених була, здебільшого, зосереджена на причинах виникнення бар'єрів та непорозумінь у ході міжкультурного спілкування та можливих способах їх подолання, вивченні поведінки у міжкультурному оточенні, зокрема, для успішного ведення професійної діяльності, управління персоналом чи налагодження ділових відносин між комунікантами. Більше уваги слід приділяти персональному розвитку особистості майбутнього спеціаліста для ефективної міжкультурної комунікативної взаємодії, формуванню його культурних переконань та цінностей, а також розвитку його як особистостіпрофесіонала для задоволення вищезазначених потреб.

Висновки і перспективи подальших досліджень. Таким чином, до важливих аспектів професійної підготовки майбутнього фахівця туристичного профілю для здійснення міжкультурної комунікативної взаємодії у професійній діяльності відносимо такі: усвідомлення культуротворчої функції туризму; необхідність базових психологічних знань з проблем міжкультурної комунікативної взаємодії для ціннісного освоєння світу (взаємоповага один до одного, вияв толерантності, знання про індивідуальні особливості людини, адекватність емоцій, способів і засобів спілкування діям і поведінці партнера по спілкуванню); міжкультурна складова професійної підготовки розглядається як тактика, дотримання якої допомагає майбутньому фахівцю побачити загальне й особливе в різних культурах, що їх об'єднує та розділяє, навчитися спілкуванню з позицій діалогу культур; розуміння міжкультурної комунікативної взаємодії як цілеспрямованого зв'язку між представниками різних культур, завдяки якому відбувається обмін інформацією, культурними та духовними цінностями з урахуванням унікальності кожної з культур у професійній діяльності для задоволення потреб туристів; підготовленість до усунення суперечностей спілкування (конструктивного характеру спілкування, які поглиблюють, удосконалюють і розвивають відносини, та деструктивного характеру спілкування, що руйнують відносини).

3 огляду на вищесказане застосування культурологічного підходу щодо професійної підготовки фахівця туристичної галузі, є важливим. Це, у свою чергу, зумовлює потребу наповнення навчальних програм професійної підготовки фахівців туристичної галузі культурологічним змістом та актуалізує необхідність створення відповідного навчально-методичного забезпечення цього процесу щодо набуття майбутніми фахівцями професійно важливих якостей, необхідних для успішної професійної діяльності й відповідних умінь для якісної комунікативної взаємодії з представниками інших культур.

\section{СПИСОК ВИКОРИСТАНИХ ДЖЕРЕЛ ТА ЛІТЕРАТУРИ}

1. Пазенок В. С. Філософія туризму / В. С. Пазенок, В. К. Федорченко. - К. : Кондор, 2004. - 268 с.

2. Гункевич М. Б. Сучасні тенденції процесів підготовки фахівців галузі туризму в Україні / М. Б. Гункевич // Вісник Луганського національного університету ім. Т. Шевченка. Серія: Педагогічні науки. - Ч. III. - 2013. № 18 (227). - С. 34-39.

3. Ничкало Н. Г. Дослідження проблем педагогіки і психології і туризму як складової теорії і методики професійної освіти / Н. Г. Ничкало // Туризм на порозі XXI століття : освіта, культура, екологія : матеріали міжнар. наук.-практ. конф. 18-20 жовтня 1999 р., м. Київ. - К., 1999. - 258 с.

4. Слободенюк Е. В. Туризм як чинник гуманізації відносин між народами : автореф. дис. на здобуття наук. ступеня канд. філос. наук: спец. 09.00.03 "Соціальна філософія та філософія історії" / Е. В. Слободенюк. - Одеса, 2003. - 19 с.

5. Черній Г. В. Досвід підготовки майбутніх фахівців туристичної сфери в Україні та світі [Електронний pecypc] / Г. В. Черній. - Режим доступу : http://intkonf.org/cherniy-gv-dosvid-pidgotovki-maybutnih-fahivtsivturistichnoyi-sferi-v-ukrayini-ta-sviti/. - Загол. з екрану. - Мова укр.

6. Квартальнов В. А. Иностранный туризм : [монография] / В. А. Квартальнов. - М. : Финансы и статистика, 1999. $-312 \mathrm{c}$.

7. Якса Н. В. Теоретичні засади професійно-педагогічної підготовки майбутніх учителів до взаємодії суб'єктів освітнього процесу в умовах полікультурності Кримського регіону : [монографія] / Н. В. Якса. - Житомир : Вид-во ЖДУ ім. Івана Франка, 2006. - 433 с.

8. Свдокімова-Лисогор Л. А. Підготовка майбутніх фахівців сфери туризму до міжкультурного діалогу в процесі вивчення соціогуманітарних дисциплін : автореф. на здобуття наук. ступеня канд. пед. наук : спец: 13.00.04 "Теорія і методика професійної освіти" / Л. А. Свдокімова-Лисогор. - Кропивницький, 2018. $24 \mathrm{c}$.

9. Радомський І. П. Культура та стилі спілкування педагога, рівні розвитку культури педагогічного спілкування / І. П. Радомський // Наукові записки ВДПУ. - Вінниця, 2005. - Вип. 14. - С. 82-84. - (Серія : Педагогіка і психологія). 
10. Головашенко О. В. Туризм як форма соціальної активності людини : соціально-філософський аналіз : автореф. дис. на здобуття наук. ступеня канд. філос. наук : спец. 09.00.03 "Соціальна філософія та філософія історії" / О. В. Головашенко. - Запоріжжя, 2002. - 18 с.

\section{REFERENCES (TRANSLATED \& TRANSLITERATED)}

1. Pazenok V. S. Filosofiia turyzmu [Tourism Philosophy] / V. S. Pazenok, V. K. Fedorchenko. - K. : Kohdor, 2004. $268 \mathrm{~s}$.

2. Hunkevych M. B. Suchasni tendentsii protsesiv pidhotovky fakhivtsiv haluzi turysmu v Ukraini [Modern Tendencies of Tourism Specialists Training Processes in Ukraine] / M. B. Hunkevych // Visnuk Luhanskogo natsional'nogo Universytetu im. T. Shevchenka. Seriia: Pedahohichni nauky [Bulletin of Luhansk National University named after T. Shevchenko. Pedagogical Sciences ]. - Ch. III. - 2013. - № 18 (227). - S. 34-39.

3. Nychkalo N. H. Doslidzhennia problem pedahohiky i psuholohii i turyzmu yak skladovoi teorii i metodyky profesiinoi osvity [Investigation of Issues in Pedagogy, Psychology and Tourism as Components of Professional Education Methodology] / N. H. Nychkalo // Turyzm na porozi XXI stolittia: osvita, kul'tura, ekolohia : materialy mizhnar.nauk.-prakt.konf. 18-20 zhovtnia 1999 r., m. Kyiv [Tourism on the Verge of the XXI Century: Education, Culture, Ecology: Materials of International Scientific and Practical Conference]. - K., 199. - 258 s.

4. Slobodeniuk E. V. Turyzm yak chynnyk humanizatsii vidnosyn mizh narodamy [Tourism as a Factor of Relationships' Humanisation between Peoples] : avtoref. dys. na zdobuttia nauk. stupenia kand. filos. nauk : spets. 09.00.03 "Sotsial'na filosofia ta filosofia istorii" / E. V. Slobodeniuk. - Odesa, 2003. - $19 \mathrm{~s}$.

5. Chernii H. D. Dosvid pidhotovky maibutnikh fakhivtsiv turystychnoi sfery v Ukraini ta sviti [Experience of Future Tourism Sphere Specialists' Training in Ukraine and in the World ] [Elektronnyi resurs]. - Rezhym dostupu : http://intkonf.org/cherniy-gv-dosvid-pidgotovki-maybutnih-fahivtsiv-turistichnoyi-sferi-v-ukrayini-ta-sviti/. - Zahol. z ekranu. - Mova ukr.

6. Kvartalnov V. A. Inostrannyi tyrizm [Foreign Tourism] : [monohrafia] / V. A. Kvartalnov. - M. : Financy i statistika, 1999. - $312 \mathrm{~s}$.

7. Yaksa N.V. Teoretychni zasady professiino-pedahohichnoi pidhotovky maibutnikh uchyteliv do vzaiemodii subiektiv osvitnioho prozesu v umovakh polikul'turnosti Krymskoho rehionu [Theoretical Fundamentals of Future Teachers' Professional and Pedagogical Training for the Interaction with the Subjects of Educational Process in Polycultural Conditions in Crimea Region] : [monohrafia] / N. V. Yaksa. - Zhytomyr : Vyd-vo ZHDU im.Ivana Franka, 2006. $-433 \mathrm{~s}$.

8. Yevdokimova-Lysohor L. A. Pidhotovka maibutnikh fakhivtsiv sfery turyzmu do mizhkul'turnoho dialohu v protsesi vyvchennia sotsiohumanitarnykh dystsyplin [Training of Future Tourism Specialists for Intercultural Dialogue in the Process of Social and Humanitarian Disciplines' Learning] : avtoref. dys. na zdobuttia nauk.stupenia kand. ped. nauk : spets: 13.00 .04 " Teoriia i metodyka profesiinoi osvity" / L. A. Yevdokimova-Lysohor. - Kropyvnytskyi, 2018. $-24 \mathrm{~s}$.

9. Radomskui I. P. Kul'tura ta styli spilkuvannia pedahoha, rivni rozvytku kul'tury pedahohichnoho spilkuvannia [Culture and Styles of Pedagogical Communication, Levels of Pedagogical Communicative Culture Development] / I. P. Radomskui // Naukovi zapysky VDPU [Scientific Notes of VDPU] - Vinnytsia, 2005. - Vyp. 14. - S. 82-84. (Seriia : Pedahohika i Psyholohiia).

10. Holovashenko O. V. Turyzm yak forma sotsial'noi aktyvnosti liudyny : sotsial'no-filosofs'kyi analiz [Tourism as a Form of Social Activeness : Social and Philosophical Analysis] : avtoref. dys. na zdobuttia nauk.stupenia kand. filos. nauk : spets. 09.00.03 "Sotsial'na filosofia ta filosofia istorii" / O. V. Holovashenko. - Zaporizhzhia, 2002. - $18 \mathrm{~s}$.

\section{Баглай О. И. Культурологический подход к профессиональной подготовке будущего специалиста туристического профиля.}

В статье обосновывается значимость культурологического подхода к профессиональной подготовке

будущего специилиста туристического профиля для осуществления межкультурного

коммуникативного взаимодействия. Отмечено, что удовлетворение постоянно растущих

потребностей потребителей туристического рынка услуг является актуальной проблемой. Отмечено, что профессиональная подготовка специалиста этой отрасли должна быть нацелена на обеспечение высокого уровня теоретической и практической подготовки специилиста, готового к осуществлению

профессиональной и коммуникативного взаимодействия с потребителями туристических услуг.

Межкультурное коммуникативное взаимодействие рассматривается как иеленаправленная связь между представителями различных культур, благодаря которому происходит обмен информаџией,

культурными и духовными ценностями с учетом уникальности каждой из культур в профессиональной деятельности, для удовлетворения потребностей туристов. Приведень основнье аспекты

профессиональной подготовки будущего специалиста туристического профиля для осуществления межкультурного коммуникативного взаимодействия в профессиональной деятельности.

Ключевые слова: профессиональная подготовка, будущий специалист туристического профиля, туристическая коммуникаиия, межкультурный диалог, межкультурное коммуникативное взаимодействие, удовлетворения потребностей туриста. 


\section{Bahlai O. I. Culturological Approach to a Future Tourism Specialist Professional Training.}

The article deals with the culturological approach and its significance for the professional training of a future tourism specialist to conduct intercultural communicative interaction. The issue of satisfaction of constantly growing needs of tourist services' market consumers serve is under the research. It is emphasized that the professional training of a specialist in this field should be aimed at providing a high level of theoretical and practical training for the specialist to be ready to conduct a professional and communicative interaction with tourist services' consumers. The scientific methods of analysis and description have been used in order to single out the main aspects to be taken into consideration whilst training future tourism specialists. It is important to integrate the work of specialists in the sphere of tourism and educational institutions through consultations, implementation of practical tasks, participation in trainings to provide an interchange of experience. One of the most important aspects of professional tourism education in Ukraine is the substantiation and research of the culturological fundamentals of tourism professional education. The author examines the communicative aspects of the specialists' training of the tourism industry for them to be able to conduct an intercultural dialogue effectively. Intercultural communicative interaction is distinguished as a purposeful link between representatives of different cultures, through which the exchange of information, cultural and spiritual values takes place, taking into account the uniqueness of each culture in professional work to meet the needs of tourists. The main aspects of the future tourism specialist professional training for the implementation of intercultural communicative interaction in professional activity are presented. As a result it has been proved that there is a need to supply the syllabuses in tourism specialist professional training with culturological content. The conclusions made certify the necessity to create appropriate educational and methodological support for the students as future tourism specialists to acquire vitally important professional qualities to live and interact in multicultural environment.

Key words: professional training, future tourism specialist, tourist communication, intercultural dialogue, intercultural communicative interaction, meeting tourist's needs. 